\title{
Partially methylated galactans containing different proportions of 3- $O$-methyl-galactose from Pleurotus citrinopileatus
}

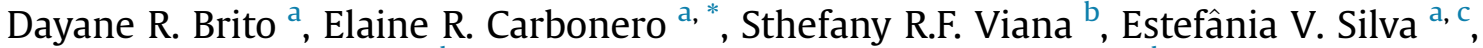 \\ Andrea Caroline Ruthes ${ }^{\mathrm{d}}$ e, ${ }^{\text {, Luciano M. Lião }}{ }^{\mathrm{c}}$, Marcello Iacomini ${ }^{\mathrm{d}}$ \\ a Departamento de Química, Universidade Federal de Goiás, Regional Catalão, 75704-020 Catalão, Brazil \\ b Departamento de Engenharia Rural, Faculdade de Ciências Agronômicas, Universidade Estadual Paulista “Julio de Mesquita Filho", 18610-307 Botucatu, \\ Brazil \\ ${ }^{c}$ Laboratório de Ressonância Magnética Nuclear, Instituto de Química, Universidade Federal de Goiás, Campus Samambaia, 74001-970 Goiânia, Brazil \\ d Departamento de Bioquímica e Biologia Molecular, Universidade Federal do Paraná, 81531-980 Curitiba, Brazil \\ e Department of Entomology and Nematology, University of Florida - GCREC, 14625 County Road 672, Wimauma, FL, 33598, United States
}

\section{A R T I C L E I N F O}

\section{Article history:}

Received 6 December 2017

Received in revised form

1 February 2018

Accepted 1 February 2018

Available online 6 February 2018

\section{Keywords:}

Medicinal mushroom

Pleurotus citrinopileatus

$O$-methylated galactans

Chemical structure

\begin{abstract}
A B S T R A C T
Pleurotus citrinopileatus, popularly known as "golden oyster mushroom" have medicinal properties, which are attributed mainly to the presence of bioactive polysaccharides. In this work, two partially 3-Omethylated galactans were isolated from the fruiting bodies of this fungus, via successive aqueous extraction, followed by fractionation by freeze-thawing, and precipitation of soluble material with Fehling solution. The structural assignments were carried out using mono- and bidimensional NMR spectroscopy, monosaccharide composition, and methylation analyses. The polysaccharides were characterized as linear, partially $3-0$-methylated $(1 \rightarrow 6)$-linked $\alpha$-galactopyranans, containing only Gal and 3-O-Me-Gal, in 2:1 and 1:1 molar ratios, with molar masses of $37.6 \times 10^{3} \mathrm{~g} / \mathrm{mol}$ and $28.5 \times 10^{3} \mathrm{~g} / \mathrm{mol}$, respectively. Similar structures have been described for other Pleurotus spp., but showing a lower content of 3-O-Me-Gal.
\end{abstract}

(c) 2018 Elsevier Ltd. All rights reserved.

\section{Introduction}

Mushrooms have received great attention due mainly their nutritional value and medicinal properties. Although there are several studies about its chemical composition and health beneficial effects, they still comprise a large and untapped source of bioactive compounds [1], being the polysaccharides considered the most potent. These macromolecules have a broad spectrum of biological effects, such as antibiotic, antioxidant, antitumoral, anticoagulant, and immunostimulating activities, which are related to the wide structural diversity presented by these polymers.

Among mushrooms that are extensively known for their medicinal properties, mainly due to the presence of bioactive polysaccharides, one can find Pleurotus citrinopileatus, commonly called "golden oyster mushroom".

Preliminar data have shown that the extracts or polysaccharidic fractions of this fungus are effective in antioxidation [2,3],

\footnotetext{
* Corresponding author.

E-mail address: elaine_carbonero@ufg.br (E.R. Carbonero).
}

antigenotoxicity [4], immunomodulation [5,6], antihyperglycemic [7] and antitumor activities [8,9]. However, it is not possible to attribute a relation between structure and activity because most of the investigations were carried out with crude polysaccharide extracts or unpurified fractions. Moreover, many of these do not report the chemical structures of these polymers. Among these studies were isolated and partially chemically characterized from $P$. citrinopileatus four fractions containing $\beta$-glucans and a heteropolysaccharide constituted by mannose, galactose, arabinose and glucose, which presented potent antitumor activity against Sarcoma 180 implanted in mice [9], and one $(1 \rightarrow 3),(1 \rightarrow 6)$-linked $\beta$ glucan $\left(M_{\mathrm{w}} 450 \mathrm{kDa}\right)$ with immunomodulatory properties [5,6]. Detailed studies of structure have been presented for a branched glucan $\left(M_{\mathrm{W}} 45 \mathrm{kDa}\right)$ constituted by a backbone comprised of $(1 \rightarrow 6)-\beta$-D-glucopyranosyl units, which were substituted at 0-3 by 3-O- $\beta$-D-glucopyranosyl-D-glucopyranose [10] and for a linear $\alpha$-galactopyranan partially $3-O$-methylated $\left(M_{\mathrm{w}} 27.4 \mathrm{kDa}\right)$ formed by $(1 \rightarrow 6)$-linked $\alpha$-galactose, $(1 \rightarrow 6)$-linked $3-0$-Me- $\alpha$-galactose and $(1 \rightarrow 4)$-linked $\alpha$-glucose in a molar ratio of 3.0:1.0:0.6 [11].

We now describe the structural features of two linear $(1 \rightarrow 6)$ - 
linked $\alpha$-galactans partially 3-O-methylated isolated from the fruiting bodies of $P$. citrinopileatus, distinct of the previously reported.

\section{Experimental}

\subsection{General experimental procedure}

GC-MS analysis was performed with an Agilent 7820A gas chromatograph interfaced to an Agilent 5975E quadrupole mass spectrometer, fitted with split/splitless capillary inlet system, an Agilent G4513A autosampler, and a capillary DB 225-MS column ( $30 \mathrm{~m} \times 0.25 \mathrm{~mm}$ i.d.). Injections of $1 \mu \mathrm{L}$ were made in the splitless mode at injection temperature of $250{ }^{\circ} \mathrm{C}$ and detector at $280^{\circ} \mathrm{C}$. The column oven temperature was initially held at $50^{\circ} \mathrm{C}$ for $1 \mathrm{~min}$, then it was programmed at $40^{\circ} \mathrm{C} \cdot \mathrm{min}^{-1}$ to $220^{\circ} \mathrm{C}$ or $210^{\circ} \mathrm{C}$ (constant temperature) for quantitative analysis of alditol acetates and partially $\mathrm{O}$-methylated alditol acetates, respectively. Helium was the carrier gas at a flow rate of $1 \mathrm{~mL} \cdot \mathrm{min}^{-1}$. Electron impact (EI) analysis was performed with the ionisation energy set at $70 \mathrm{eV}$.

NMR spectra $\left({ }^{1} \mathrm{H},{ }^{13} \mathrm{C}\right.$, HSQC-DEPT, COSY, HMBC, HSQC-TOCSY, and HSQC-NOESY) were obtained using a $500 \mathrm{MHz}$ Bruker Avance spectrometer incorporating Fourier transform. Analyses were performed at 50 or $70^{\circ} \mathrm{C}$ on samples dissolved in $\mathrm{D}_{2} \mathrm{O}$. Chemical shifts are expressed in $\delta$ relative to the internal standard tetramethylsilane (TMS) $\left(\delta=0.0\right.$ for ${ }^{13} \mathrm{C}$ and $\left.{ }^{1} \mathrm{H}\right)$.

\subsection{Macrofungus and culture conditions}

Fresh Pleurotus citrinopileatus (950 g) was furnished by Yuki Cogumelos Company (Owner: José Francisco Ramos Fernandes Viana), located in Araçoiaba da Serra, State of São Paulo, Brazil, in
December 2013. The fungus was grown on culture substrate constituted of eucalyptus sawdust, wheat bran, corn bran, and calcitic limestone in a mixture ratio by weight of 137.5:27.0:30.5:1.0, with 62\% relative humidity. After homogenization, the substrate was filled into polyethylene bags ( $2 \mathrm{~kg}$ each), autoclaved for $90 \mathrm{~min}$ at $121^{\circ} \mathrm{C}$ and $1 \mathrm{~atm}$. After the substrates were cooled down to room temperature, each bag was inoculated with $20 \mathrm{~g}$ of mushroom spawn. The inoculated substrates were kept in a spawn running room at $23^{\circ} \mathrm{C}$ for 20 days. When the mycelium fully covered the substrate bag (spawn run completed), bags were kept open in a cropping room in which the temperature was controlled at $19{ }^{\circ} \mathrm{C}$, relative humidity at $85-90 \%$.

\subsection{Extraction and purification of galactans}

The fresh fruiting bodies of $P$. citrinopileatus (950 $\mathrm{g}$ ) were dried by lyophilization, pulverized and the polysaccharides extracted with water at $10^{\circ} \mathrm{C}$ for $6 \mathrm{~h}(\mathrm{x} 1,1000 \mathrm{~mL})$. The extract was filtered and after centrifugation at $9000 \mathrm{rpm}$ at $20^{\circ} \mathrm{C}$ for $20 \mathrm{~min}$ a clear solution was obtained. The polysaccharides were precipitated by addition of excess EtOH $(3: 1 ; \mathrm{v} / \mathrm{v})$ to the concentrated supernatant, and then recovered by centrifugation at $9000 \mathrm{rpm}$ at $10^{\circ} \mathrm{C}$ for 20 min. The crude polysaccharide fraction was dissolved in $\mathrm{H}_{2} \mathrm{O}$, dialyzed against distilled water for $20 \mathrm{~h}$ to remove low-molecularweight carbohydrates, and freeze-dried, giving rise to fraction $\mathrm{CW}$ $P c$. This fraction was then dissolved in distilled water and the solution submitted to freezing followed by mild thawing at $4{ }^{\circ} \mathrm{C}$ [12], giving cold water-soluble (SCW-Pc) and insoluble fractions (ICW$P c)$, which were separated by centrifugation (9000 rpm at $10^{\circ} \mathrm{C}$ for $20 \mathrm{~min})$. SCW-PC fraction was treated with Fehling's solution $(15 \mathrm{~mL})$ [13], and the precipitated material (FP-Pc) centrifuged off (9000 rpm at $10^{\circ} \mathrm{C}$ for $20 \mathrm{~min}$ ). Both FP-Pc (precipitate), after

\begin{tabular}{|c|c|}
\hline \multicolumn{2}{|c|}{$\begin{array}{c}\text { Fruiting bodies of } \boldsymbol{P} \text {. citrinopileatus } \\
\text { (Dried weight }=135.9 \mathrm{~g} \text { ) }\end{array}$} \\
\hline & $\mathrm{H}_{2} \mathrm{O}$ at $10^{\circ} \mathrm{C}$ for $6 \mathrm{~h}(\mathrm{x} 1)$ \\
\hline Residue I & $\begin{array}{l}\text { Aqueous extract } \\
\operatorname{EtOH}(3: 1 ; \mathrm{v} / \mathrm{v}) \mid\end{array}$ \\
\hline Ethanol supernatant & $\begin{array}{l}\text { Ethanol precipitate } \\
\quad(\mathrm{CW}-P c, 14.7 \mathrm{~g}) \\
\text { Freeze-thawing; } \\
\text { Centrifugation. }\end{array}$ \\
\hline $\begin{array}{l}\text { Insoluble fraction } \\
(\mathrm{ICW}-P c, 1.1 \mathrm{~g})\end{array}$ & $\begin{array}{l}\text { Soluble fraction } \\
(\mathrm{SCW}-P c, 13.5 \mathrm{~g})\end{array}$ \\
\hline
\end{tabular}

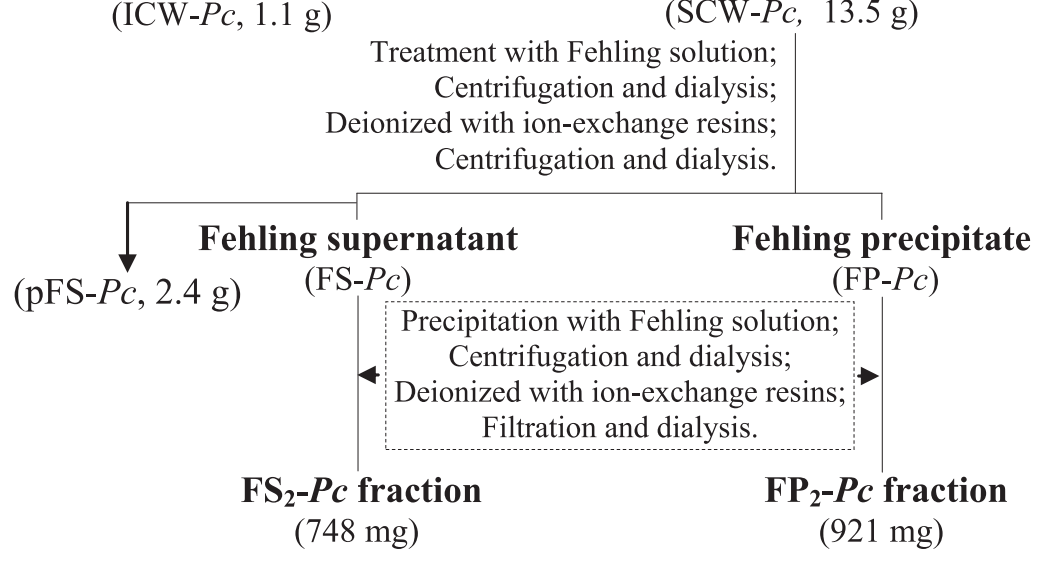

Fig. 1. Scheme of extraction and purification of the polysaccharides from P. citrinopileatus. 
dissolution with destilled water, and FS-Pc (supernatant) fractions, were neutralized with HOAc, dialyzed against tap water and deionized with strongly acidic cation exchange resin (Dowex ${ }^{\circledR}$ $50 \mathrm{WX} 2$ hydrogen form), till total removal of the blue/green color characteristic of copper presence. During the treatment with ionexchange resins, part of FS-Pc fraction became precipitated (pFS$P c$ fraction). The resin was removed by filtration through a nylon woven filter and the filtrate centrifuged under same conditions above, giving fractions FS-Pc and pFS-Pc. Fehling treatment was repeated one more cycle under fractions FP-PC and FS-PC, giving the fractions $\mathrm{FP}_{2}-\mathrm{Pc}$ and $\mathrm{FS}_{2}-\mathrm{Pc}$, respectively.

\subsection{Monosaccharide composition}

Monosaccharide components of the polysaccharides were identified and their ratios were determined following hydrolysis with $1 \mathrm{M}$ TFA for $8 \mathrm{~h}$ at $100^{\circ} \mathrm{C}$, and conversion to alditol acetates (GC-MS) by successive $\mathrm{NaBH}_{4}$ and/or $\mathrm{NaBD}_{4}$ reduction, and acetylation with $\mathrm{Ac}_{2} \mathrm{O}$-pyridine $(1: 1, \mathrm{v} / \mathrm{v})$ for $12 \mathrm{~h}$ at room temperature $[14,15]$. The resulting alditol acetates were analyzed by gas chromatography-mass spectrometry (GC-MS) as above cited (item 2.1) and identified by their typical retention times and electron impact profiles.

\subsection{Determination of homogeneity of polysaccharides and their molecular weight}

The homogeneity and molar mass $\left(M_{\mathrm{w}}\right)$ of the water-soluble fractions were determined by high performance steric exclusion chromatography (HPSEC), using a refractive index (RI) detector and a Wyatt Technology Dawn-F Multi-Angle Laser Light Scattering detector (MALLS). The eluent was $0.1 \mathrm{M} \mathrm{NaNO}_{3}$, containing $0.5 \mathrm{~g} / \mathrm{L}$ $\mathrm{NaN}_{3}$. The polysaccharide solutions were filtered through a membrane, with pores of $0.22 \mu \mathrm{m}$ diameter (Millipore). The specific refractive index increment $(d n / d c)$ was determined. The samples were dissolved in $50 \mathrm{mM} \mathrm{NaNO}$, and five increasing concentrations, ranging from 0.2 to $1.0 \mathrm{mg} / \mathrm{mL}$, were used to determine the slope of the increment.

\subsection{Methylation analysis of polysaccharides}

Per- $O$-methylation of the purified fractions ( $5 \mathrm{mg}$ each) was carried out using $\mathrm{NaOH}-\mathrm{Me}_{2} \mathrm{SO}-\mathrm{MeI}$ [16]. The per-O-methylated derivatives ( $1 \mathrm{mg}$ ) were hydrolyzed with $45 \% \mathrm{v} / \mathrm{v}$ formic acid $\left(\mathrm{HCO}_{2} \mathrm{H}, 250 \mu \mathrm{l}\right)$ at $100^{\circ} \mathrm{C}$ for $12 \mathrm{~h}$, followed by evaporation to dryness. The resulting mixture of $\mathrm{O}$-methylaldoses was reduced with $\mathrm{NaBD}_{4}$ and acetylated with $\mathrm{Ac}_{2} \mathrm{O}$-pyridine $(1: 1, \mathrm{v} / \mathrm{v})$ for $12 \mathrm{~h}$ at room temperature $[14,15]$ to give a mixture of partially $O$-methylated alditol acetates, which was analyzed by GC-MS, and identified from $m / z$ of their positive ions, by comparison with standards. The results were expressed as a relative percentage of each component.

\section{Results and discussion}

The basidiocarps (fruiting bodies) of $P$. citrinopileatus (950 g) were reduced to $14.3 \%$ of the original weight after desiccation in a freeze dryer. The powder was submitted to one extraction with water at $10^{\circ} \mathrm{C}$, and the extracted polysaccharides were recovered as

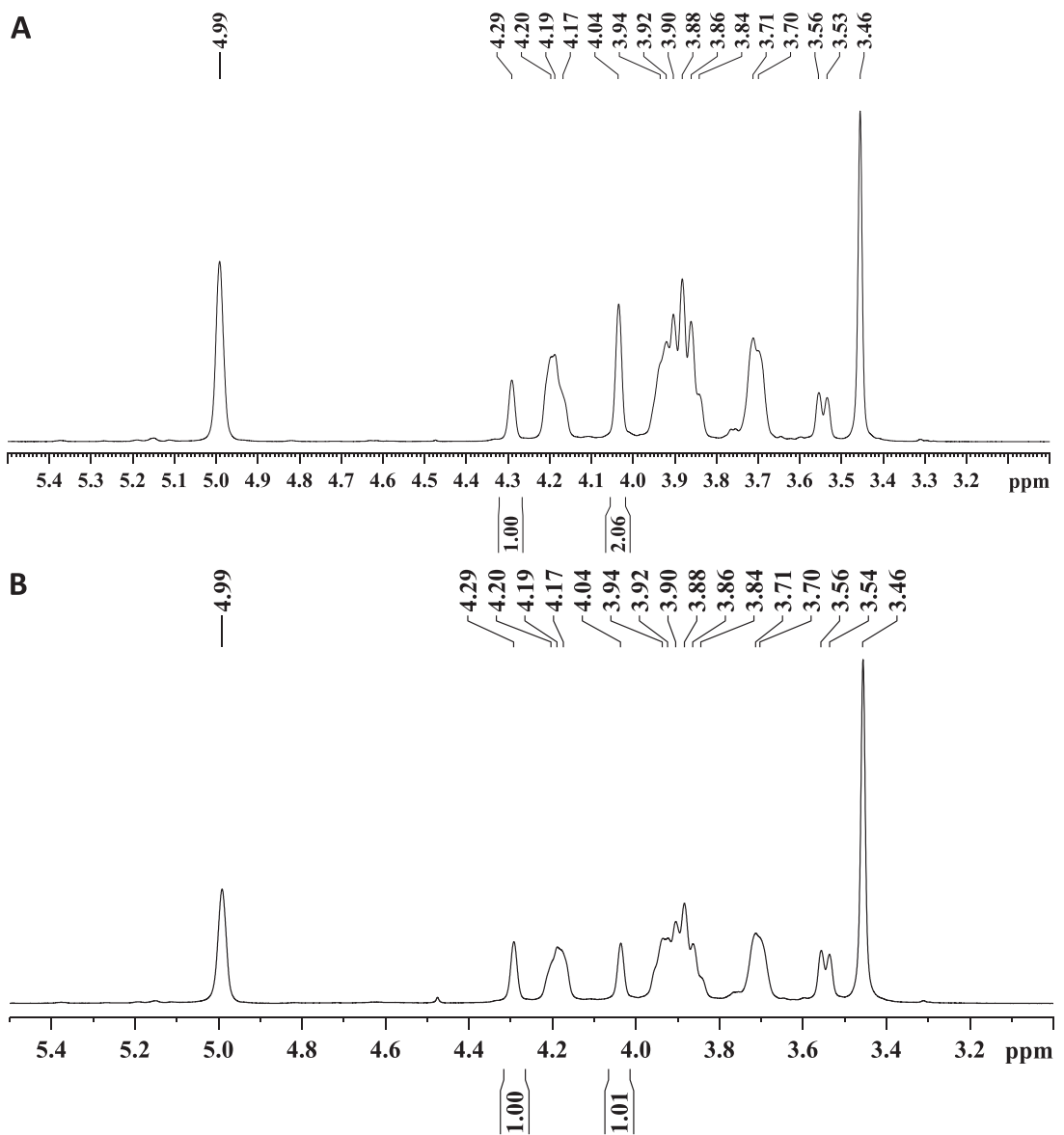

Fig. 2. ${ }^{1} \mathrm{H}$ NMR spectra of $\mathrm{FP}_{2}-\mathrm{Pc}(\mathrm{A})$ and $\mathrm{FS}_{2}-\mathrm{Pc}(\mathrm{B})$ fractions, in $\mathrm{D}_{2} \mathrm{O}$ at $50{ }^{\circ} \mathrm{C}(500 \mathrm{MHz})$. 

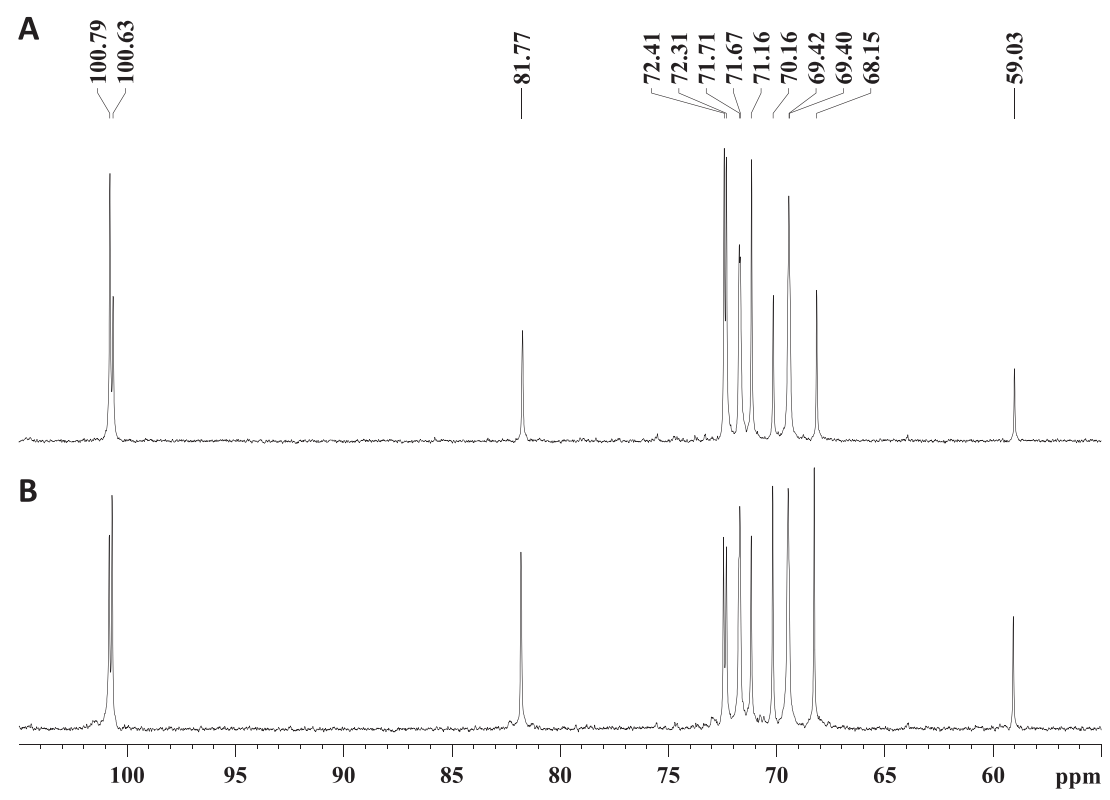

Fig. 3. ${ }^{13} \mathrm{C}$ NMR spectra of galactans $\left(\mathbf{A}\right.$ : $\mathrm{FP}_{2}-\mathrm{Pc}$; $\left.\mathbf{B}: \mathrm{FS}_{2}-\mathrm{PC}\right)$ from $P$. citrinopileatus, in $\mathrm{D}_{2} \mathrm{O}$ at $70{ }^{\circ} \mathrm{C}(125 \mathrm{MHz})$.

ethanol precipitate, dialysis against tap water, and freeze-dried (fraction CW-Pc, $14.7 \mathrm{~g}$ ) (Fig. 1).

CW-Pc fraction showed to be composed by galactose $(49.2 \%)$ as main monosaccharide, besides of mannose (15.7\%), 3-O-Megalactose (16.6\%) [confirmed by the presence of the ions at $\mathrm{m} / \mathrm{z} 130$ and 190 , after reduction $\left(\mathrm{NaBD}_{4}\right)$ and acetylation], and glucose
(11.6\%), according to GC-MS of derived alditol acetates.

Fractionation and purification of CW-Pc extract was carried out by a freeze-thawing procedure [12], which resulted in a respective cold water-soluble (SCW-Pc, $13.5 \mathrm{~g}$ ) and an -insoluble (ICW-Pc, $1.1 \mathrm{~g}$ ) fraction, which were separated by centrifugation. SCW-PC contained galactose (47.9\%), 3-O-methylgalactose (19.9\%), mannose (24.8\%), and

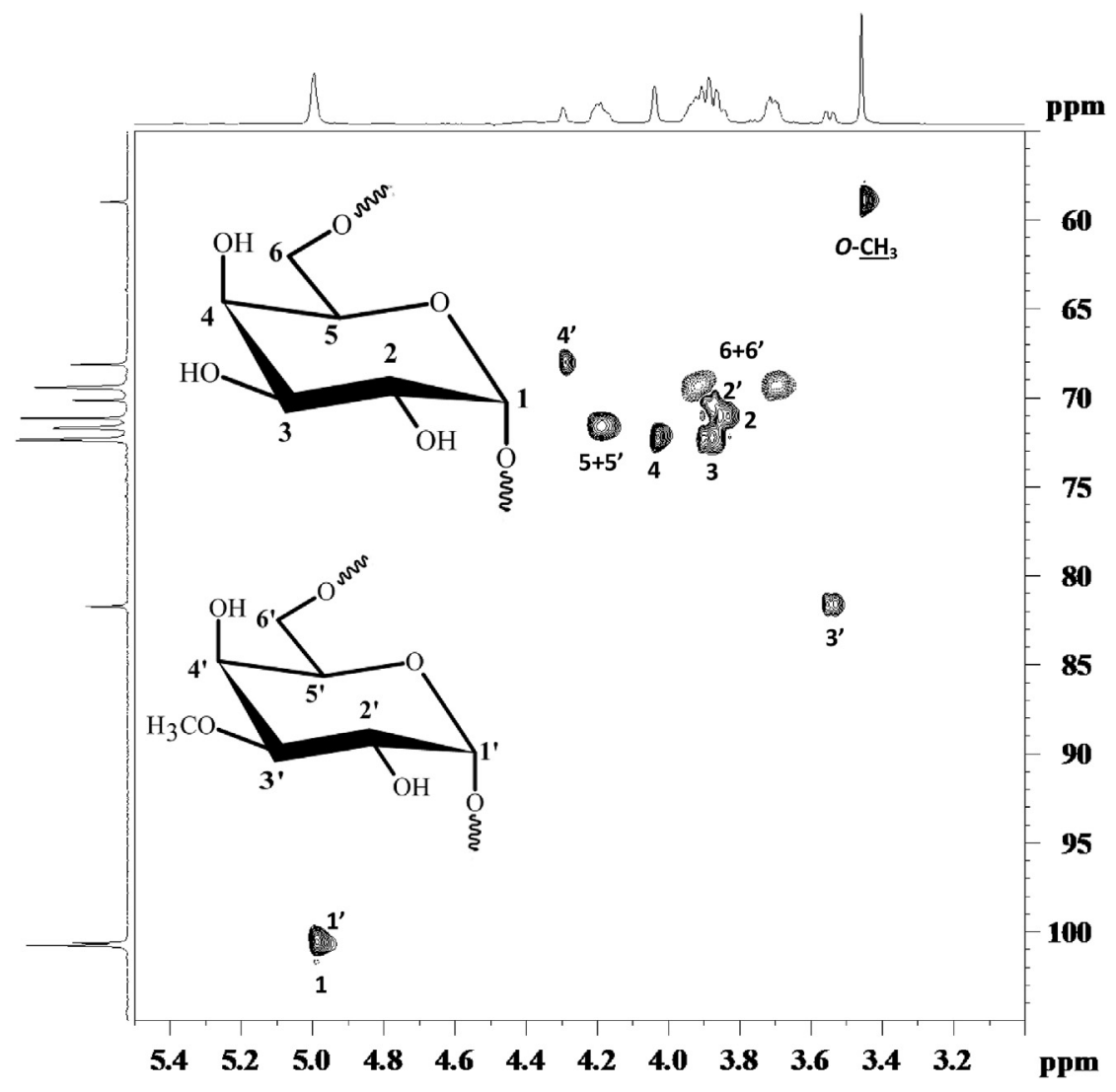

Fig. 4. $\mathrm{HSQC}-\mathrm{DEPT}$ spectrum of $\mathrm{FP}_{2}-P c$ fraction obtained from $P$. citrinopileatus, in $\mathrm{D}_{2} \mathrm{O}$ at $50{ }^{\circ} \mathrm{C}$. 
Table 1

${ }^{1} \mathrm{H}$ and ${ }^{13} \mathrm{C}$ NMR chemical shifts of galactans from $P$. citrinopileatus. ${ }^{\mathrm{a}, \mathrm{b}}$

\begin{tabular}{|c|c|c|c|c|c|c|c|c|c|}
\hline \multirow[t]{2}{*}{ Units } & & \multirow[t]{2}{*}{1} & \multirow[t]{2}{*}{2} & \multirow[t]{2}{*}{3} & \multirow[t]{2}{*}{4} & \multirow[t]{2}{*}{5} & \multicolumn{2}{|l|}{6} & \multirow[t]{2}{*}{$-\mathrm{O}-\underline{\mathrm{CH}}$} \\
\hline & & & & & & & $6 a$ & $6 b$ & \\
\hline \multirow[t]{2}{*}{$\rightarrow 6)-\alpha-$ Galp- $(1 \rightarrow$} & ${ }^{13} \mathrm{C}$ & 100.79 & 71.14 & 72.41 & 72.31 & 71.71 & 69.39 & - & - \\
\hline & ${ }^{1} \mathrm{H}$ & 4.998 & 3.84 & 3.86 & 4.04 & 4.20 & 3.70 & 3.90 & - \\
\hline \multirow[t]{2}{*}{$\rightarrow 6)-3-0$-Me- $\alpha$-Galp- $(1 \rightarrow$} & ${ }^{13} \mathrm{C}$ & 100.63 & 70.16 & 81.77 & 68.15 & 71.67 & 69.40 & - & 59.03 \\
\hline & ${ }^{1} \mathrm{H}$ & 4.986 & 3.89 & 3.56 & 4.29 & 4.18 & 3.71 & 3.92 & 3.46 \\
\hline
\end{tabular}

a Assignments are based on ${ }^{1} \mathrm{H},{ }^{13} \mathrm{C}$, HSQC-DEPT, HSQC-TOCSY, and COSY examination.

b The values of chemical shifts were recorded with reference to TMS as internal standard.

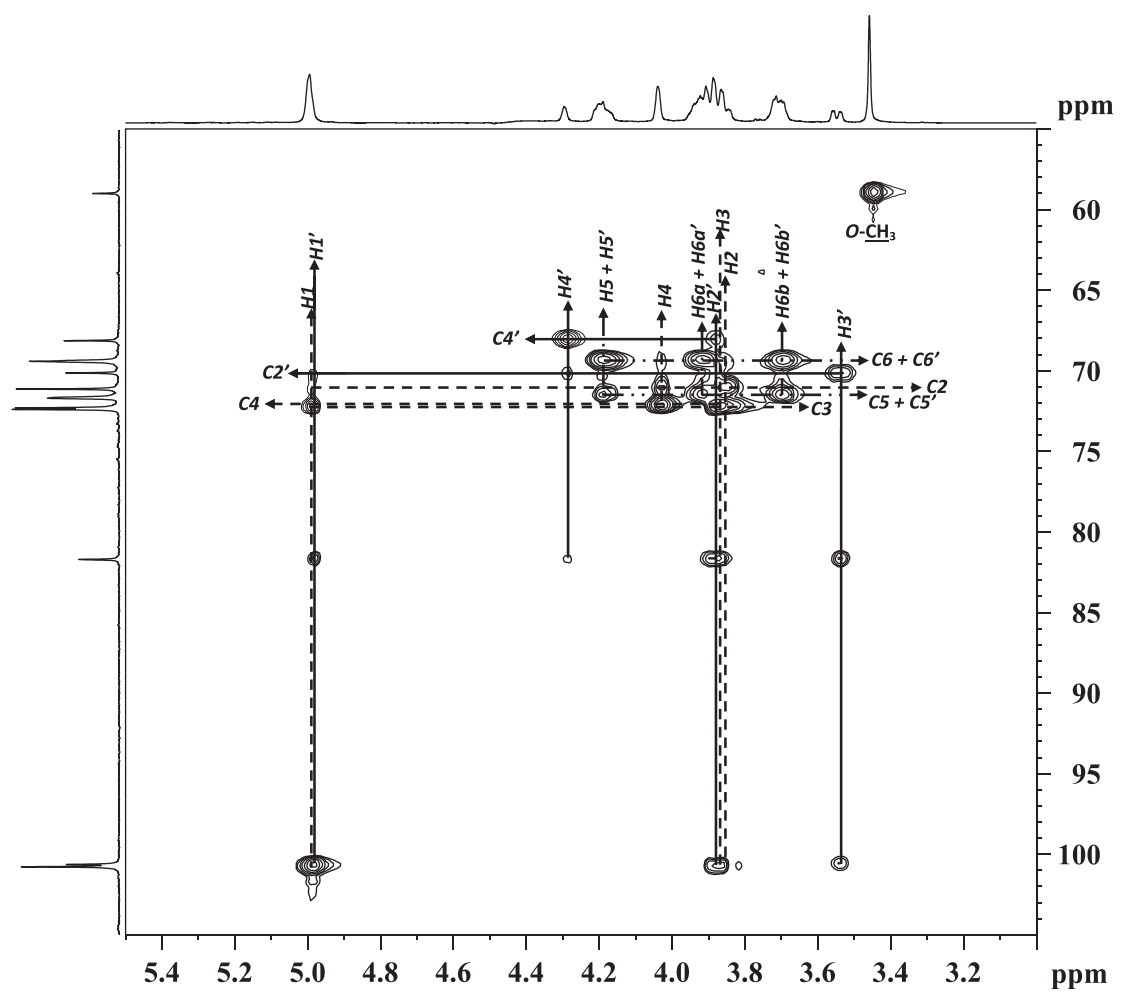

Fig. 5. HSQC-TOCSY spectrum of $\mathrm{FP}_{2}-P c$ fraction obtained from $P$. citrinopileatus, in $\mathrm{D}_{2} \mathrm{O}$ at $50^{\circ} \mathrm{C}$.

glucose (7.4\%), and HPSEC-MALLS analysis showed heterogeneity. This fraction was then treated with Fehling solution two times sequentially, giving rise to a precipitate $\left(\mathrm{FP}_{2}-\mathrm{Pc} ; 921 \mathrm{mg}\right)$ and a supernatant $\left(\mathrm{FS}_{2}-\mathrm{Pc} ; 748 \mathrm{mg}\right)$. Part of the latter fraction becaming insoluble during treatment with ion-exchange resins (pFS-Pc; $2.4 \mathrm{~g}$ )
(Fig. 1).

After treatment with $\mathrm{Cu}^{+2}$ solution, $\mathrm{FP}_{2}-\mathrm{Pc}$ and $\mathrm{FS}_{2}-\mathrm{Pc}$ fractions gave homogeneous HPSEC elution profiles, and had

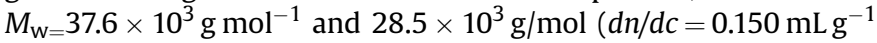
for both fractions), respectively. The monosaccharide compositions

Table 2

The significant connectivities observed in HSQC-TOCSY spectrum of the galactans from the P. citrinopileatus.

\begin{tabular}{|c|c|c|}
\hline \multirow[t]{2}{*}{ Units } & \multirow[t]{2}{*}{$\mathrm{H} / \mathrm{C} \delta_{\mathrm{H}} / \delta_{\mathrm{C}}$} & Observed cross peaks \\
\hline & & $\delta_{\mathrm{H}} / \delta_{\mathrm{C}}($ Atom $)$ \\
\hline \multirow[t]{6}{*}{$\rightarrow 6)-\alpha-D-G a l p-(1 \rightarrow$} & $100.79(\mathrm{C} 1)$ & $4.998(\mathrm{H} 1) ; 3.86(\mathrm{H} 3) ; 3.84(\mathrm{H} 2)$ \\
\hline & $71.14(\mathrm{C} 2)$ & $4.998(\mathrm{H} 1) ; 4.04(\mathrm{H} 4) ; 3.86(\mathrm{H} 3) ; 3.84(\mathrm{H} 2)$ \\
\hline & $72.41(\mathrm{C} 3)$ & \\
\hline & $72.31(\mathrm{C} 4)$ & \\
\hline & $71.71(\mathrm{C} 5)$ & 4.20 (H5); 3.90 (H6a); 3.70 (H6b) \\
\hline & $69.39(\mathrm{C} 6)$ & $4.20(\mathrm{H} 5) ; 4.04(\mathrm{H} 4) ; 3.90(\mathrm{H} 6 \mathrm{a}) ; 3.70(\mathrm{H} 6 \mathrm{~b})$ \\
\hline \multirow{7}{*}{$\rightarrow 6)-3-O-M e-\alpha-D-G a l p-(1 \rightarrow$} & $100.63(\mathrm{C} 1)$ & $4.986(\mathrm{H} 1) ; 3.89(\mathrm{H} 2) ; 3.56(\mathrm{H} 3)$ \\
\hline & $70.16(\mathrm{C} 2)$ & $4.986(\mathrm{H} 1) ; 4.29(\mathrm{H} 4) ; 4.18(\mathrm{H} 5) ; 3.89(\mathrm{H} 2) ; 3.56(\mathrm{H} 3)$ \\
\hline & $81.77(\mathrm{C} 3)$ & $4.986(\mathrm{H} 1) ; 4.29(\mathrm{H} 4) ; 3.89(\mathrm{H} 2) ; 3.56(\mathrm{H} 3)$ \\
\hline & $68.15(C 4)$ & $4.29(\mathrm{H} 4) ; 3.89(\mathrm{H} 2)$ \\
\hline & $71.67(\mathrm{C} 5)$ & $4.18(\mathrm{H} 5) ; 3.92(\mathrm{H6a}) ; 3.71(\mathrm{H} 6 \mathrm{~b})$ \\
\hline & $69.39(\mathrm{C} 6)$ & \\
\hline & $59.03\left(-\mathrm{O}-\mathrm{CH}_{3}\right)$ & $3.46\left(-\mathrm{O}-\mathrm{C}_{3}\right)$ \\
\hline
\end{tabular}


of $\mathrm{FP}_{2}-\mathrm{Pc}$ and $\mathrm{FS}_{2}-\mathrm{Pc}$ fractions were similar. 3-O-methylgalactose (3$O$-Me-Gal) and galactose (Gal) were present in a 1:2 and 1:1 molar ratio, respectively, suggesting the presence of partially methylated galactans. The molar ratios of 3-O-Me-Gal and Gal determined by GC-MS as alditol acetates were confirmed by integration area of well-resolved $\mathrm{H}-4$ signals ( $\delta 4.29$ and 4.04 for $3-O-M e-G a l$ and Gal units, respectively) in ${ }^{1} \mathrm{H}$ NMR spectrum (Fig. 2).

The ${ }^{13} \mathrm{C}$ NMR spectra of the galactans from the two fractions of $P$. citrinopileatus were similar (Fig. $3 \mathrm{~A}$ and $\mathrm{B}$ ), with variations in the intensity of signals corresponding of the 3-O-methylgalactose units.

In order to elucidate the structures of the galactans, further NMR spectroscopy analyses (HSQC-DEPT, COSY, and HSQC-TOCSY) were carried out for both fractions, but due to their great similarity only the data obtained for $\mathrm{FP}_{2}-\mathrm{Pc}$ fraction were illustrated. Since coupling of protons $(\mathrm{H}-1$ to $\mathrm{H}-4$ and $\mathrm{H}-5 / \mathrm{H}-6)$ of each of the units observed in COSY spectrum, the assignments of respective ${ }^{13} \mathrm{C}$ signals were established using HSQC-DEPT analysis (Fig. 4; Table 1), which were confirmed by correlations in HSQC-TOCSY spectrum (Fig. 5; Table 2).

The $\alpha$-configuration was shown by high frequency $\mathrm{H}-1$ signals $(\delta$ 4.998 and 4.986) and low frequency C-1 signals ( $\delta 100.79$ and $100.63)$, and the O- 6 substitution indicated by the inversion of C-6 signals of Galp ( $\delta 69.39 / 3.90 ; 3.70)$, and 3-O-Me-Galp ( $\delta 69.40 / 3.92$; 3.71) units, in the HSQC-DEPT spectrum (Fig. 4; Table 1).

HMBC and HSQC-NOESY experiments were carried out, but it was not possible to determine the sequence of units in this polymer due to overlapping signals.

In order to confirm the linkage type of this polymer, both fractions were submitted to methylation analysis, which showed only the alditol acetates of 2,3,4-Me $\mathrm{Mal}_{3}$, and traces of 2,3,4,6-Me $4 \mathrm{Gal}$.

In summary, the above results show that the purified polysaccharides $\left(\mathrm{FP}_{2}-\mathrm{Pc}\right.$ and $\mathrm{FS}_{2}-\mathrm{Pc}$ fractions) consisted of linear $(1 \rightarrow 6)$-linked $\alpha$-galactopyranans partially 3-O-methylated, with differences in the molar mass and levels of methyl groups (Gal and 3-O-Me-Gal, in 2:1 and 1:1 molar ratios, respectively). Similar structures have been isolated from fruiting bodies of Pleurotus citrinopileatus [11], P. eryngii, and $P$. ostreatoroseus [17], but containing Gal and 3-O-Me-Gal, in a 3:1 molar ratio.

Partially 3 - $O$-methylated $(1 \rightarrow 6)$-linked $\alpha$-galactopyranans have been described only for this genus, suggesting to be characteristic of the "oyster mushroom". However, it has been observed that the amounts of 3-O-Me-Gal seems to be influenced probably by some factor related to cultivation, fungal strain, among others.

\section{Acknowledgements}

The authors would like to thank the Brazilian funding agencies
CAPES (Coordenação de Aperfeiçoamento de Pessoal de Nível Superior), $\mathrm{CNPq}$ (Conselho Nacional de Desenvolvimento Científico e Tecnológico) and FAPEG (Fundação de Amparo à Pesquisa do Estado de Goiás) for financial support, and the Universidade Federal de São Carlos (UFSCar) for carrying out 2D NMR experiments.

\section{References}

[1] S.P. Wasser, Current findings, future trends, and unsolved problems in studies of medicinal mushrooms, Appl. Microbiol. Biotechnol. 89 (2011) 1323-1332.

[2] Y.L. Lee, G.W. Huang, Z.C. Liang, J.L. Mau, Antioxidant properties of three extracts from Pleurotus citrinopileatus, LWT-Food Sci. Technol 40 (2007) $823-833$.

[3] S.Q. Wu, S.L. Gao, H.H. Liu, X.Y. Sun, L. Hao, L. Jia, L.F. Pang, S.H. Jia, M.S. Jia, Intracellular polysaccharide and its antioxidant activity by Pleurotus citrinopileatus SM-01, Macromol. Res. 21 (2013) 660-668.

[4] J.C. Wang, S.H. Hu, Z.C. Liang, M.Y. Lee, Antigenotoxicity of extracts from Pleurotus citrinopileatus, J. Sci. Food Agric. 85 (2005) 770-778.

[5] K.I. Minato, Immunomodulation activity of a polysaccharide fraction of a culinary-medicinal mushroom, Pleurotus citrinopileatus Singer (Agaricomycetideae), in vitro, Int. J. Med. Mushrooms 10 (2008) 235-244.

[6] K.I. Minato, L.C. Laan, A. Ohara, I. van Die, Pleurotus citrinopileatus polysaccharide induces activation of human dendritic cells through multiple pathways, Int. Immunopharmacol. 40 (2016) 156-163.

[7] S.H. Hu, J.C. Wang, J.L. Lien, E.T. Liaw, M.Y. Lee, Antihyperglycemic effect of polysaccharide from fermented broth of Pleurotus citrinopileatus, Appl. Microbiol. Biotechnol. 70 (2006) 107-113.

[8] J.C. Wang, S.H. Hu, Z.C. Liang, C.J. Yeh, Optimization for the production of water-soluble polysaccharide from Pleurotus citrinopileatus in submerged culture and its antitumor effect, Appl. Microbiol. Biotechnol. 67 (2005) 759-766.

[9] J. Zhang, G. Wang, H. Li, C. Zhuang, T. Mizuno, H. Ito, C. Suzuki, H. Okamoto, J. Li, Antitumor polysaccharides from a Chinese mushroom, "yuhuangmo," the fruiting body of Pleurotus citrinopileatus, Biosci. Biotechnol. Biochem. 58 (1994) 1195-1201.

[10] J. Liu, Y. Sun, H. Yu, C. Zhang, L. Yue, X. Yang, L. Wang, J. Liu, Purification and identification of one glucan from golden oyster mushroom (Pleurotus citrinopileatus (Fr.) Singer), Carbohydr. Polym. 87 (2012) (2012) 348-352.

[11] P. He, A. Zhang, S. Zhou, F. Zhang, R.J. Linhardt, P. Sun, Structural elucidation of polysaccharide containing 3-O-methylgalactose from fruiting bodies of Pleurotus citrinopileatus, Carbohydr. Res. 434 (2016) 72-76.

[12] P.A.J. Gorin, M. Iacomini, Polysaccharides of the lichens Cetraria islandica and Ramalina usnea, Carbohydr. Res. 128 (1984) 119-132.

[13] J.K.N. Jones, R.J. Stoodley, Fractionation using copper complexes, Methods Carbohydr. Chem. 5 (1965) 36-38.

[14] M.L. Wolfrom, A. Thompson, Reduction with sodium borohydride, in: R.L. Whistler, M.L. Wolfrom (Eds.), Methods Carbohydr. Chem, Academic Press, New York, 1963a, pp. 65-68.

[15] M.L. Wolfrom, A. Thompson, Acetylation, in: R.L. Whistler, M.L. Wolfrom (Eds.), Methods Carbohydr. Chem, Academic Press, New York, 1963b, pp. $211-215$.

[16] I. Ciucanu, F. Kerek, A simple and rapid method for the permethylation of carbohydrates, Carbohydr. Res. 131 (1984) 209-217.

[17] E.R. Carbonero, A.H.P. Gracher, M.C.C. Rosa, G. Torri, G.L. Sassaki, P.A.J. Gorin, M. Iacomini, Unusual partially 3-O-methylated $\alpha$-galactan from mushrooms of the genus Pleurotus, Phytochemistry 69 (2008) 252-257. 